\title{
Interactive and Single Effects of Ectomycorrhiza Formation and Bacillus cereus on Metallothionein MT1 Expression and Phytoextraction of $\mathrm{Cd}$ and $\mathrm{Zn}$ by Willows
}

\author{
Katarzyna Hrynkiewicz • Grazyna Dabrowska • \\ Christel Baum • Katarzyna Niedojadlo • \\ Peter Leinweber
}

Received: 25 March 2011 / Accepted: 3 August 2011 / Published online: 18 August 2011

(C) The Author(s) 2011. This article is published with open access at Springerlink.com

\begin{abstract}
Single and joint ectomycorrhizal (+ Hebeloma mesophaeum) and bacterial (+ Bacillus cereus) inoculations of willows (Salix viminalis) were investigated for their potential and mode of action in the promotion of cadmium (Cd) and zinc ( $\mathrm{Zn})$ phytoextraction. Dual fungal and bacterial inoculations promoted the biomass production of willows in contaminated soil. Single inoculations either had no effect on the plant growth or inhibited it. All inoculated willows showed increased concentrations of nutritional elements (N, P, K and Zn) and decreased
\end{abstract}

K. Hrynkiewicz $\cdot$ C. Baum $\cdot$ P. Leinweber

Soil Science, University of Rostock,

Justus-von-Liebig-Weg 6,

18059 Rostock, Germany

K. Hrynkiewicz $(\bowtie)$

Department of Microbiology, Institute of General and

Molecular Biology, N. Copernicus University of Torun,

Torun, Poland

e-mail: hrynk@umk.pl

K. Hrynkiewicz

e-mail: hrynk@biol.uni.torun.pl

G. Dabrowska

Department of Genetics, Institute of General and Molecular Biology, N. Copernicus University of Torun,

Torun, Poland

K. Niedojadlo

Department of Cell Biology, Institute of General and Molecular Biology, N. Copernicus University of Torun, Torun, Poland concentrations of $\mathrm{Cd}$ in the shoots. The lowest biomass production and concentration of $\mathrm{Cd}$ in the willows $(+B$. cereus) were combined with the strongest expression of metallothioneins. It seems that biotic stress from bacterial invasion increased the synthesis of these stress proteins, which responded in decreased $\mathrm{Cd}$ concentrations. Contents of $\mathrm{Cd}$ and $\mathrm{Zn}$ in the stems of willows were combination-specific, but were always increased in dual inoculated plants. In conclusion, single inoculations with former mycorrhiza-associated B. cereus strains decreased the phytoextraction efficiency of willows by causing biotic stress. However, their joint inoculation with an ectomycorrhizal fungus is a very promising method for promoting the phytoextraction of $\mathrm{Cd}$ and $\mathrm{Zn}$ through combined physiological effects on the plant.

Keywords Salix viminalis $\cdot$ Ectomycorrhiza . Phytoremediation $\cdot$ Metallothioneins

\section{Introduction}

Willows (Salix spp.) are common pioneer tree species in metal-contaminated soils in Central Europe as they are highly metal-tolerant (Hrynkiewicz et al. 2008). Therefore, they can be used successfully for phytoextraction of heavy metals from contaminated soils (Zacchini et al. 2009). Inoculation of willows with suitable microorganisms seems to be a promising strategy to promote the phytoextraction of metals 
from contaminated soils (Wenzel 2009; Zimmer et al. 2009). Mycorrhiza formation can efficiently ameliorate abiotic stress of the host plant (Jentschke and Godbold 2000; Hall 2002; Hrynkiewicz et al. 2008). This is mainly based on exclusion processes, e.g., absorption of metals by the hyphal sheath, reduced access to the apoplast due to hydrophobicity of the fungal sheath, chelation by fungal exudates, and sorption onto the external mycelium (Hall 2002). Exclusion of metals by mycorrhizal fungi can decrease the phytoextraction of metals by willows (Bissonnette et al. 2010). However, this effect can be compensated by the significant promotion of plant growth due to the mycorrhizal fungal associations (Baum et al. 2006).

Symbiosis between host plants and mycorrhizal fungi can be enhanced by associated bacteria that can support mycorrhiza formation and function (Hrynkiewicz et al. 2010b). Associated bacteria can also increase the efficiency of mycorrhizal fungi for the acceleration of phytoremediation (Zimmer et al. 2009). This can be caused by enzymatic mobilization of nutrients from organic matter and synthesis of plant hormones or vitamins (Belimov et al. 2001; Whiting et al. 2001; Vessey 2003; Compant et al. 2005; Jing et al. 2007; Kuffner et al. 2008; Hrynkiewicz et al. 2010b). Furthermore, bacterial siderophores can mobilize heavy metals and enhance the metal uptake of plants ( $\mathrm{Hu}$ and Boyer 1996).

Associated Bacillus spp. from ectomycorrhizal roots of willows (Salix viminalis) on disturbed arable and landfill soils revealed especially high enzymatic activities (Hrykiewicz et al. 2010a). Bacillus cereus was also among the dominant bacterial species isolated from ectomycorrhizal roots of Pinus sylvestris L. at a heavy metal-contaminated site (Kozdrój et al. 2007). In general, B. cereus is widespread in nature and is frequently isolated from soil and plants (Arnesen et al. 2008). Since endospores of Bacillus spp. have remarkable longevity and resistance to harsh environmental conditions (Arnesen et al. 2008), this genera seem to include promising inocula for heavy metal-contaminated soils. B. cereus has been shown to promote arbuscular mycorrhiza formation (Artursson and Jansson 2003) and increase biomass production and heavy metal tolerance of Trifolium repens, especially in combination with arbuscular mycorrhizal fungi (Azcón et al. 2010). However, the potential of $B$. cereus to promote ectomycorrhiza formation and extraction of heavy metals by willows is yet unknown.

Plants have developed several strategies for high heavy metal tolerance, like the expression of metallothioneins (MTs) and phytochelatins (DalCorso et al. 2008). Since phytochelatins seem to be missing or below the level of detection in S. viminalis (Landberg and Greger 2004; Wang and Greger 2004), the present work focused on MTs. To the best of our knowledge, the expression of MTs in $S$. viminalis has not been investigated so far, although this species is used for extraction of metals during remediation of contaminated soils. MTs are cystein-rich proteins with low molecular weight, which maintain intracellular ion homeostasis and contribute to the detoxification of heavy metal ions (Zhu et al. 2010). On the basis of the predicted location of cystein-rich proteins, further categories as types 1 and 2 have been designated (Scott and Albert 2005). The impact of MTs on heavy metal tolerance was investigated in several plants as, e.g., Vicia faba (Foley et al. 1997), Bruguiera gymnorrhiza (Huang and Wang 2009), Oryza sativa (Chun-Juan et al. 2010) and Piper nigrum (Ozkuthu et al. 2006). Metallothioneins can affect the metal concentrations in the plant biomass, and hence, the efficiency of metal extraction. For instance, an inserted metallothionein in transgenic tabacco increased the $\mathrm{Cd}$ concentrations in the plant shoots (Janoušková et al. 2005).

The expression of MTs in plants can be significantly affected by ectomycorrhiza formation (Voiblet et al. 2001). Therefore, increased tolerance to abiotic stress in ectomycorrhizal plants might be promoted by an increased expression of MTs. Also bacterial strains, e.g., the plant pathogenic species Xanthomonas campestris, can affect the expression of MTs in their host plants based on biotic stress (Obertello et al. 2007).

We hypothesized that $B$. cereus could either promote ectomycorrhizal effects on the phytoextraction of metals by promotion of mycorrhiza formation and plant growth or, alternatively, inhibit metal extraction of willows by an increased expression of MTs caused by biotic stress through bacterial invasion in the roots.

The objectives of the present study were to investigate (i) effects of single and joint inoculation of willows with an EM fungus (Hebeloma mesophaeum) and B. cereus strains on mycorrhiza forma- 
tion, growth and metal extraction of willows, (ii) the magnitude of strain-specific differences within the species $B$. cereus, and, (iii) the expression of MT1 in mycorrhizal and nonmycorrhizal willows and consequences for the phytoextraction.

\section{Material and Methods}

2.1 Pot Experiment and Specification of Microorganisms Used as Inoculum

Cuttings of $S$. viminalis clone 78-101 (5 cm long, provided by the Institute of Forest Genetics and Plant Breeding in Waldsieversdorf, Germany), were planted in polyethylene pots filled with heavy metalcontaminated soil $(1.0 \mathrm{~kg})$ from a floodplain of the

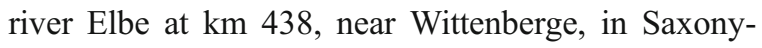
Anhalt, Germany. The soil properties were: $\mathrm{C}_{\mathrm{org}}$ $55.0 \mathrm{~g} \mathrm{~kg}^{-1}, \mathrm{~N}_{\mathrm{t}} 4.2 \mathrm{~g} \mathrm{~kg}^{-1}, \mathrm{pH}\left(\mathrm{CaCl}_{2}\right)$ 5.1, clay $335 \mathrm{gkg}^{-1}$, silt $420 \mathrm{gkg}^{-1}$, sand $245 \mathrm{gkg}^{-1}, \mathrm{Cd}_{\mathrm{t}}$ $7.8 \mathrm{mg} \mathrm{kg}^{-1}, \mathrm{Zn}_{\mathrm{t}} 762.6 \mathrm{mg} \mathrm{kg}^{-1}, \mathrm{Cu}_{\mathrm{t}} 164.1 \mathrm{mg} \mathrm{kg}^{-1}$, and $\mathrm{Pb}_{\mathrm{t}} 181.5 \mathrm{mg} \mathrm{kg}^{-1}$. Before use, the dry soil was sieved $(<5 \mathrm{~mm})$.

The microbial strains were isolated from ectomycorrhizal roots of Salix caprea or fruit bodies from two metal-contaminated sites in the former silver mining area around Freiberg in Central Germany (Lichtloch, LIC, $50^{\circ} 56^{\prime} \mathrm{N}, 13^{\circ} 18^{\prime} \mathrm{E}$ and Münzbachtal, MUN, $50^{\circ} 55^{\prime} \mathrm{N}, 13^{\circ} 17^{\prime} \mathrm{E}$ ). For a detailed description of these two test sites see Hrynkiewicz et al. (2008). Mycelium of the ectomycorrhizal fungus $H$. mesophaeum $(\mathrm{Hm})$ was isolated from a fruit body growing near S. caprea at MUN (Table 1). Four B. cereus strains were selected as inocula for the pot experiment and designated as B1 to B4. They were isolated from ectomycorrhizal roots of $S$. caprea formed by Tomentella and Hebeloma spp. (B. cereus B1-B3) and from a fruit body of $H$. mesophaeum (B. cereus B3) (see Table 1). All strains were identified based on their DNA sequence analysis. The DNA of the B. cereus strains was isolated using Dneasy ${ }^{\circledR}$ Blood \& Tissue Kit (Qiagen, Hilden, Germany). The amplification of the 16S rRNA gene was performed using the primers F1 (5'-GAG TTT GAT CCT GGC TCA G-3') and R12 (5'-ACG GCT ACC TTG TTA CGA CTT-3') (Dorsch and Stackebrandt 1992). The PCR parameters, sequencing of received products and BLAST searching were performed according to Hrynkiewicz et al. (2010a). The DNA of the fungal strains was isolated from frozen mycorrhizal samples (EM roots or fruit bodies) using the DNAeasy Plant Mini Kit (Qiagen, Hilden, Germany). The internal transcribed spacer (ITS) within the ribosomal RNA genes was

Table 1 Specification of the ectomycorrhiza forming fungal and bacterial strains used as inoculum in the pot experiment

\begin{tabular}{|c|c|c|c|c|c|}
\hline & Abbr. & Identification and acc. no. & $\begin{array}{l}\text { Closest BLAST match in } \\
\text { GenBank NCBI }\end{array}$ & $\%$ similarity & Source of isolation \\
\hline Fungus & $\mathrm{Hm}$ & $\begin{array}{l}\text { Hebeloma mesophaeum } \\
\text { [HQ453395] }\end{array}$ & $\begin{array}{l}\text { Hebeloma mesophaeum } \\
\text { [AB211272] } \\
\text { Hebeloma mesophaeum } \\
\text { [EF644106] }\end{array}$ & $\begin{array}{l}677 / 680(99 \%) \\
664 / 668(99 \%)\end{array}$ & $\begin{array}{l}\text { Fruit body of } H \text {. } \\
\text { mesophaeum-MUN }\end{array}$ \\
\hline \multirow[t]{4}{*}{ Bacteria } & B1 & $\begin{array}{r}\text { Bacillus cereus } \\
\text { [HM989918] }\end{array}$ & $\begin{array}{l}\text { Bacillus cereus CrK20 } \\
\text { [GQ503329] } \\
\text { Bacillus cereus } \text { MZQ-ZJ01 } \\
\text { [GQ407269] }\end{array}$ & $\begin{array}{l}1419 / 1419(100 \%) \\
1419 / 1419(100 \%)\end{array}$ & $\begin{array}{l}\text { Ectomycorrhizae of } \\
\text { Tomentella sp.-MUN }\end{array}$ \\
\hline & B2 & $\begin{array}{r}\text { Bacillus cereus } \\
\text { [HM989916] }\end{array}$ & $\begin{array}{l}\text { Bacillus cereus } \mathrm{MZQ}-\mathrm{ZJ} 01 \\
\text { [GQ407269] } \\
\text { Bacillus cereus } \mathrm{W}-2 \\
\text { [EU187485] }\end{array}$ & $\begin{array}{l}1412 / 1412(100 \%) \\
1412 / 1412(100 \%)\end{array}$ & $\begin{array}{l}\text { Ectomycorrhizae of } \\
\text { Hebeloma sp.-LIC }\end{array}$ \\
\hline & B3 & $\begin{array}{r}\text { Bacillus cereus } \\
\text { [HM989917] }\end{array}$ & $\begin{array}{l}\text { Bacillus cereus CrK20 } \\
\text { [GQ503329] } \\
\text { Bacillus cereus MZQ-ZJ01 } \\
\text { [GQ407269] }\end{array}$ & $\begin{array}{l}1403 / 1403(100 \%) \\
1403 / 1403(100 \%)\end{array}$ & $\begin{array}{l}\text { Ectomycorrhizae of } \\
\text { Tomentella sp.-LIC }\end{array}$ \\
\hline & B4 & $\begin{array}{r}\text { Bacillus cereus } \\
\text { [HM989919] }\end{array}$ & $\begin{array}{l}\text { Bacillus cereus ATCC } 21281 \\
\text { [FJ501984] } \\
\text { Bacillus cereus B33 } \\
\text { [FJ483513] }\end{array}$ & $\begin{array}{l}1410 / 1410(100 \%) \\
1410 / 1410(100 \%)\end{array}$ & $\begin{array}{l}\text { Fruit body of } H . \\
\text { mesophaeum-MUN }\end{array}$ \\
\hline
\end{tabular}


amplified using the primers ITS1F and ITS4 (Gardes and Bruns 1993). The PCR assays, sequencing and BLAST search were done according to Hrynkiewicz et al. (2009). DNA sequences determined for this study were deposited in GenBank and Accession Numbers were given (Table 1).

The EM inoculum was prepared in Melin-Norkrans broth (Kottke et al. 1987) and washed twice in sterile water. Five milliliters of fungal inoculum was applied twice in 2 week intervals to the soil under growing plants. Bacterial inoculum was grown in liquid R2A medium (Difco) at $25^{\circ} \mathrm{C}$ for $36 \mathrm{~h}$, suspended in $0.1 \mathrm{M}$ $\mathrm{MgSO}_{4}$ buffer, washed twice and resuspended in distilled water. The bacterial inoculation suspensions $\left(10 \mathrm{ml}\right.$ of $10^{8} \mathrm{cfu}$ per $\left.\mathrm{ml}\right)$ were applied around the cutting 2 weeks after the fungal inoculation. Bacterial density was measured as absorbance of the suspension at $600 \mathrm{~nm}$ with reference to a standard curve calibrated by plate enumeration. The controls were treated in the same way, but with sterilized $\left(121^{\circ} \mathrm{C}, 20 \mathrm{~min}, 1 \mathrm{bar}\right)$ inocula. Nine treatments were established in total: one noninoculated control (Ctr), five single inoculated treatments with EM (H. mesophaeum) or with one of the four B. cereus strains (B1-B4) and four dual inoculated treatments with $H$. mesophaeum and one of the $B$. cereus strains. Each treatment was replicated five times (45 pots in total). Plants were grown in a greenhouse at $25^{\circ} \mathrm{C}$ and $12 \mathrm{hday} / 12 \mathrm{~h}$ night conditions under sodium lighting system $\left[100 \mu \mathrm{mol} \mathrm{m} \mathrm{s}^{2}\right.$ PAR (photosynthetically active radiation)]. They were irrigated with distilled water. No fertilizers were applied. After 3 months, shoots and roots of the plants were harvested. EM fine root tips were calculated on the basis of percentage of total investigated root tips. The stems were oven-dried at $65^{\circ} \mathrm{C}$ until constant weight and measured.

\subsection{Analysis of Elements}

The stems were ground to $<0.5 \mathrm{~mm}$ by a mill (Retsch $\mathrm{GmbH}$, Haan, Germany) for the determination of nutrient $(\mathrm{N}, \mathrm{P}, \mathrm{K}$ and $\mathrm{Zn})$ and $\mathrm{Cd}$ concentrations. $\mathrm{N}$ concentrations of the leaves were determined with Foss Heraeus CNS-Vario EL (Elementar Analysentechnik GmbH, Germany). Concentrations of P, K, Cd and $\mathrm{Zn}$ were determined with inductively coupled plasma optical emission spectroscopy (ICP-OES, JY 238, Jobin Yvon, France) after digestion with $\mathrm{HNO}_{3}$. The relative standard deviations (RSD) of replicate element analyses in the digests were $<2 \%$. The total $\mathrm{Cd}$ and $\mathrm{Zn}$ uptake by the willows was calculated by multiplying mean values of biomass [g DW] and metal concentrations $\left[\mathrm{mg} \mathrm{kg}^{-1}\right]$ of each treatment.

\subsection{Determination of Metallothioneins}

Isolation of RNA Leaf samples were collected from willows grown in all treatments in the heavy metalpolluted soil and one sample was collected from noninoculated willows grown in a noncontaminated soil (negative control). Total RNA was extracted from $100 \mathrm{mg}$ of plant tissue using Universal RNA Purification Kit (Eurx Sp. z o.o., Gdańsk). Quality and quantity of RNA were assessed spectrophotometrically and by analysis on $1 \%$ agarose gel electrophoresis stained with EtBr (Fig. 3a). Reverse transcription (RT) was performed to obtain cDNA for PCR reaction. The primers Sv1 (5'-TGGCTTGTTTGAATTCTTCC-3') and Sv2 (5'-TCATTTGCAAGTGCATGGAT-3') were used to amplify fragment of gene $M T 1$ of $S$. viminalis. To design primers Sv1 and Sv2, the sequence coding Met1 gene of Salix matsudana (GenBank NCBI Acc. No. EF157299) was used. The PCR reaction was carried out under the following conditions: $5 \mathrm{~min} 95^{\circ} \mathrm{C}$, 35 cycles $\left(95^{\circ} \mathrm{C} 45 \mathrm{~s}, 58^{\circ} \mathrm{C} 60 \mathrm{~s}, 72^{\circ} \mathrm{C} 60 \mathrm{~s}\right), 10 \mathrm{~min}$ $72^{\circ} \mathrm{C}$. The PCR products (306 bp) were subcloned into pJET1.2 (Fermentas) and sequenced.

Northern Hybridization Ten micrograms of total RNA was separated in $1.2 \%(\mathrm{w} / \mathrm{v})$ agarose-formaldehyde denaturing gel and blotted onto a nylon membrane Hybond-N ${ }^{+}$(Sigma) using the standard capillary method according to the protocol of Sambrook et al. (1989). Prehybridization and hybridization were conducted in the DIG Easy Hyb (Roche) buffer at $68^{\circ} \mathrm{C}$ with PCR product used as the molecular probe. Unbounded molecular probe was deleted through a double rinsed membrane in Low Stringency Buffer and High Stringency Buffer (Roche). Detection was conducted according to the DIG Nucleic Acid Detection Kit protocol (Roche). The membrane was exposed to an X-ray film (Roche) for $3 \mathrm{~h}$.

\subsection{Electron Microscopy}

Cleared ectomycorrhizas and adjacent parts of the roots were suspended in distilled water. Samples of 
EM roots were fixed overnight at $4{ }^{\circ} \mathrm{C}$ with $2.5 \%$ glutaraldehyde in $0.1 \mathrm{M}$ phosphate-buffered saline (PBS) $\mathrm{pH}$ 7.2. The first $1 \mathrm{~h}$ of the fixation was carried out in a vacuum pump at $4^{\circ} \mathrm{C}$ (Xu et al. 1995). After washing in PBS $\mathrm{pH} 7.2$, material was postfixed with $1 \% \mathrm{OsO}_{4}$ in PBS pH 7.2 for $2 \mathrm{~h}$ at $4^{\circ} \mathrm{C}$. Samples were washed, dehydrated in graded concentrations of ethanol up to $100 \%$ and embedded in LR Gold (Sigma) with $1 \%$ benzoyl peroxide as the polymerization accelerator. The Poly/Bed 812 resin polymerized during heating at $60^{\circ} \mathrm{C}$ for 2 days. Ultrathin longitudinal sections were cut using a Leica UTC ultramicrotome, collected on the nickel grids coated with $0.3 \%$ Formvar (Sigma) and stained with $1 \%$ phosphotungustic acid and 5\% uranyl acetate solutions. Sections were examined using a Joel EM 1010 transmission electron microscope.

\subsection{Statistical Analysis}

The data of the biomass production and ECM formation were statistically evaluated using onefactorial analysis of variance ( $p \leq 0.05$; for comparison of means) (ANOVA). Student test was used to evaluate differences between concentrations of heavy metals $(\mathrm{Cd}$ and $\mathrm{Zn}$ ) and nutrients in the leaves of willows for different treatments. All statistical analyses were performed using Statistica for Windows, release 5.1 (1996; StatSoft, Tulsa, OK, USA).

\section{Results}

3.1 Plant Growth, Mycorrhizal Colonisation, and Foliar Nutrient Concentrations

Single inoculation of S. viminalis 78-101 with the microbial strains either did not affect the biomass production (H. mesophaeum, B. cereus B3 and B4) or decreased it significantly (B. cereus $\mathrm{B} 1$ and $\mathrm{B} 2)$ in comparison to the noninoculated Ctr (Fig. 1a). The treatment with $B$. cereus strains $\mathrm{B} 2$ and $\mathrm{B} 1$ produced the lowest biomass (1.6 and 1.2 times lower than the noninoculated $\mathrm{Ctr}$, respectively). Dual inoculation with H. mesophaeum and B. cereus (B1, B2 and B3) significantly increased the biomass production in comparison to the Ctr. However, dual inoculation with use of B. cereus strain B4 decreased the biomass production.
All dual inoculated treatments revealed significantly larger portions of EM roots (24-38\% EM roots) than the single inoculated treatments with bacterial (1-2\% EM roots) or fungal inocula (17\% EM roots) (Fig. 2b). The portion of EM roots was not significantly correlated with the biomass production. However, a decreasing portion of EM roots in dual inoculated treatments $(\mathrm{Hm}+\mathrm{B} 4>$ $\mathrm{Hm}+\mathrm{B} 1>\mathrm{Hm}+\mathrm{B} 2>\mathrm{Hm}+\mathrm{B} 3)$ was combined with increasing biomass production $(\mathrm{Hm}+\mathrm{B} 4<$ $\mathrm{Hm}+\mathrm{B} 1<\mathrm{Hm}+\mathrm{B} 2<\mathrm{Hm}+\mathrm{B} 3)$.

Inoculation predominantly increased the concentrations of the nutrients (N, P and $\mathrm{K}$ ) in the leaves (Table 2). The $\mathrm{N}$ concentrations of leaves were significantly larger in all treatments with single inoculation with bacterial strains (8-27\%) and with dual inoculation with bacterial strains B4 and H. mesophaeum (35\%) than in the Ctr. The P concentrations were significantly increased only in the leaves after dual inoculation $(H$. mesophaeum with B. cereus B1 3\%, and with B4 9\%). In all other inoculated treatments, the $\mathrm{P}$ concentrations were reduced compared to the $\mathrm{Ctr}$. The $\mathrm{K}$ concentrations were significantly higher in nearly all inoculated treatments than in the $\mathrm{Ctr}(8-40 \%)$. Only after single inoculation with $B$. cereus B1 were they significantly lower than in the Ctr.

\subsection{Concentrations and Total Contents of Heavy Metals in Plants}

In general, inoculation decreased the $\mathrm{Cd}(6-38 \%)$ and increased the $\mathrm{Zn}$ (4-33\%) concentrations in the shoots compared to the Ctr (Table 2). The shoots revealed the lowest $\mathrm{Cd}$ concentrations after single inoculation with B. cereus B1-B3 (32-38\%) and dual inoculation with H. mesophaeum and B. cereus B3 and B4 (32 and $25 \%$, respectively). Single inoculations with $H$. mesophaeum or B. cereus (B3 and B4) and dual inoculations with H. mesophaeum and B. cereus (B2 and B4) increased the $\mathrm{Zn}$ concentrations in the willow shoots (19-33\%) compared to the Ctr.

Direction and magnitude of the impact of inoculation on the $\mathrm{Cd}$ and $\mathrm{Zn}$ uptake of willows differed specifically with regards to strain and combination. The Cd content in the stems increased up to $30 \%$ or decreased up to $31 \%$ and the $\mathrm{Zn}$ content increased up to $60 \%$ or decreased up to $39 \%$ after inoculation. The $\mathrm{Cd}$ and the $\mathrm{Zn}$ uptake into willow shoots were negatively correlated. 
Fig. 1 Biomass production (a) and percentage of EM root tips (b) of Salix viminalis clone $87-100$ with and without (Ctr) inoculation with EM fungus $H$. mesophaeum and four $B$. cereus strains (B1, B2, B3 and B4) in heavy metal-polluted soil $(n=4 ; P \leq 0.05)$
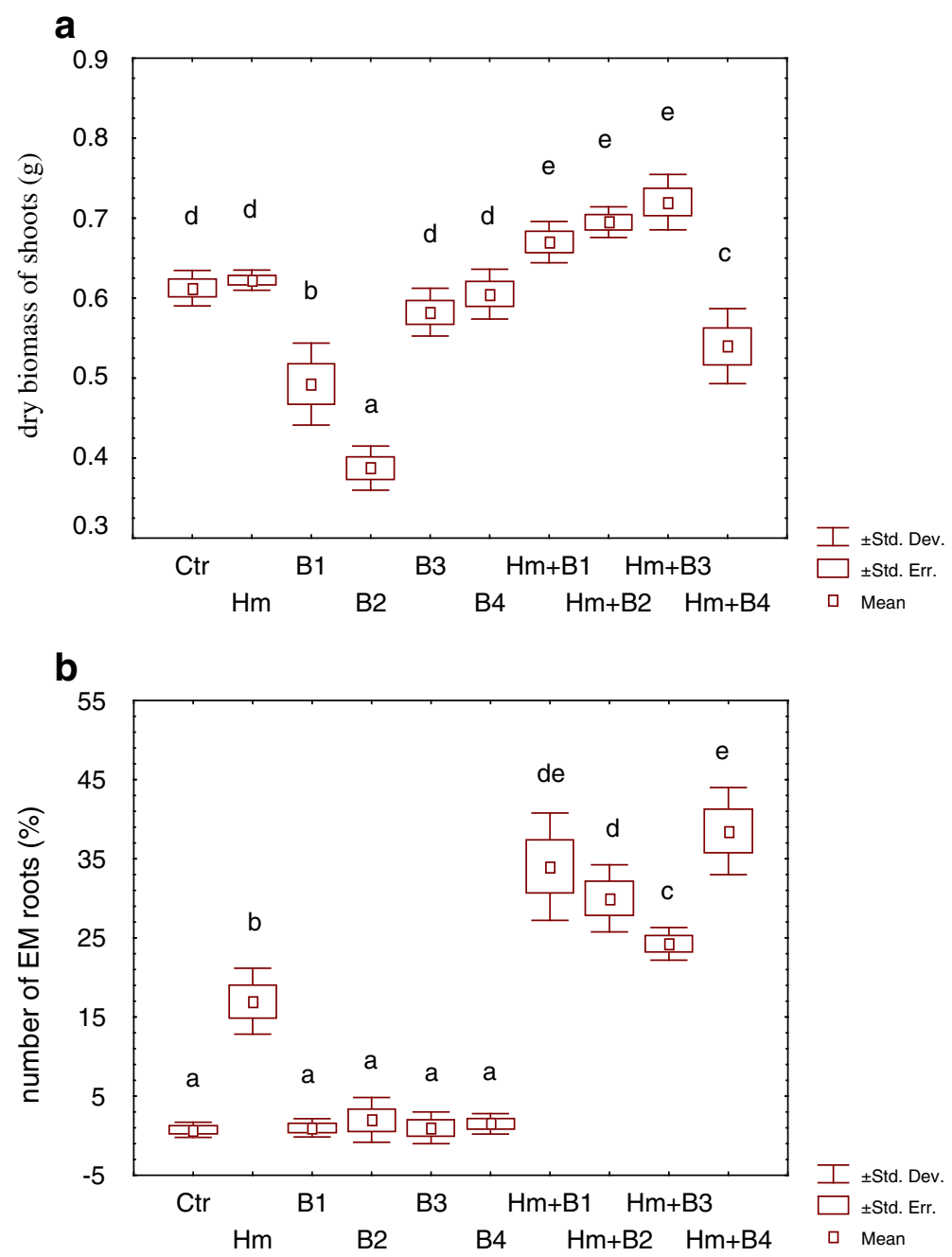

\subsection{Expression of Metallothioneins}

The inoculation of $S$. viminalis 78-101 with the microbial strains (Fig. 2a-c, lanes 2-10) increased the expression of MTs in the leaves compared to the Ctr (lane 1). Single inoculation with B. cereus B1, B2, B3 or B4 (lanes 3-6) revealed a higher expression of MTs than with $H$. mesophaeum (lane 2). The relative MT1 gene expression level (Fig. 2c) in the plants inoculated with a single bacterial strain was 1.5-4.5 times larger than in the treatment with $H$. mesophaeum. The amounts of MT1 transcripts after single inoculation with bacterial strains decreased in the following order: $\mathrm{B} 1>\mathrm{B} 2>\mathrm{B} 3 \geq \mathrm{B} 4$. Dual inoculation always decreased the expression of $M T 1$ compared to variants with single inoculation with the bacterial strains. In the plants growing in the noncontaminated soil (Fig. 3, lane 11) expression of MTs was always lower than in those from the contaminated soil (lanes 1-10).

\subsection{Microscopical Analyses of Inoculated Roots}

Only one EM morphotype was observed on the roots of $S$. viminalis clone 87-101 growing in the contaminated soil. Both unramified as well dichotomous EM roots (diameter $0.3-0.6 \mathrm{~mm}$ ) covered with white, plectenchymatous mantle (type B, according to Agerer 1987-2006) and abundant extramatrical hyphae were observed (short distance exploration type) (Fig. 4a-b). Numerous cells of $B$. cereus (white arrows) were observed inside the outer mantle of EM roots (Fig. 4c) and in the plant cells (Fig. 4d). 


\section{Increase/decrease of the content in the stem (\%)}

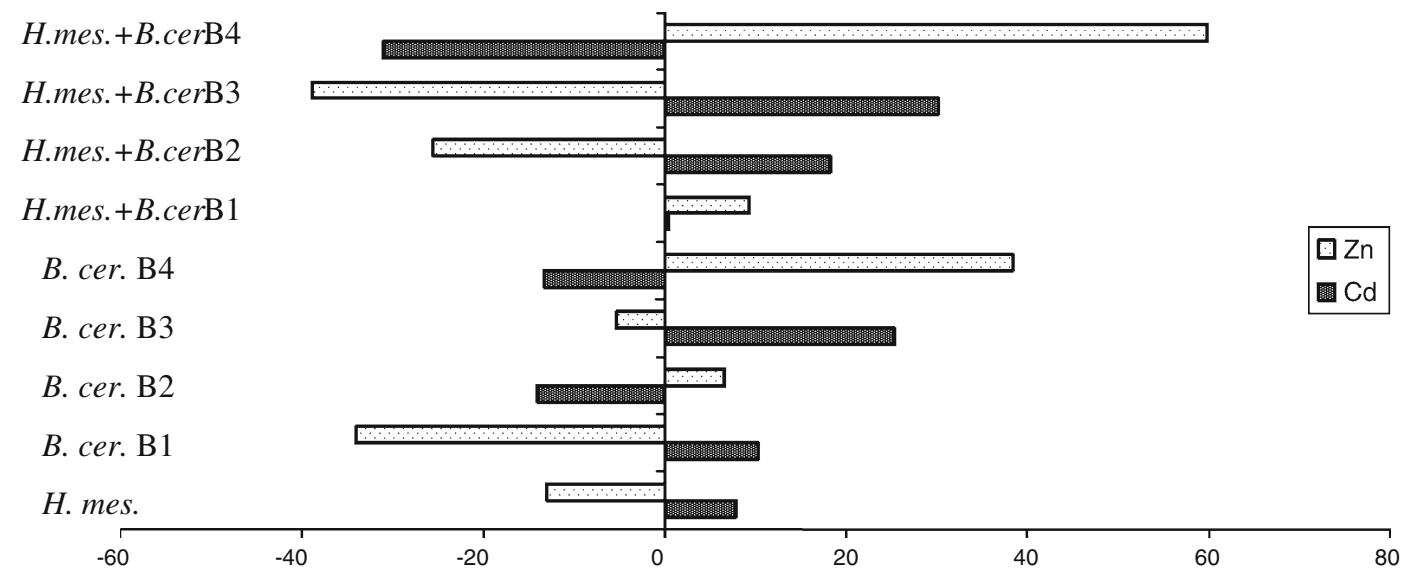

Fig. 2 Percentage of increase/decrease of the $\mathrm{Cd}$ and $\mathrm{Zn}$ content in the stems of Salix viminalis 78-101 after inoculation with the EM fungus Hebeloma mesophaeum and four strains of Bacillus cereus B1-B4 in contaminated soil

\section{Discussion}

The dual inoculation was confirmed to be more effective in the promotion of willow growth in contaminated soils than single inoculations. The presented potential of dual inoculation with EM fungi and associated bacteria to promote the willow growth agreed with the potential of other dual inoculations of willows (Zimmer et al. 2009; Kuffner et al. 2008).
Furthermore, dual inoculations of $T$. repens with arbuscular mycorrhizal fungi and $B$. cereus (Azcón et al. 2010) and of Brassica juncea with other Bacillus spp. (B. megaterium HKP-1 and B. mucilaginosus HKK-1) and Azotobacter chroococcum HKN5 (Wu et al. 2006) promoted the plant growth on polluted soils as well. This points to significant benefits of the combined use of diverse microbial activities in dual inoculations. To the best of our

Table 2 Foliar nutrient and Cd concentrations of $S$. viminalis clone 87-100 with or without (Ctr) inoculation by H. mesophaeum (Hm) and four B. cereus strains (B1, B2, B3 and B4) in the pot experiment with heavy metal-polluted soil (mean \pm S.D., $n=4$ )

\begin{tabular}{|c|c|c|c|c|c|}
\hline & \multicolumn{5}{|l|}{ Foliar concentrations } \\
\hline & $\mathrm{N}\left(\mathrm{mg} \mathrm{g}^{-1}\right)$ & $\mathrm{P}\left(\mathrm{mg} \mathrm{g}^{-1}\right)$ & $\mathrm{K}\left(\mathrm{mg} \mathrm{g}^{-1}\right)$ & $\mathrm{Cd}\left(\mu \mathrm{g} \mathrm{g}^{-1}\right)$ & $\mathrm{Zn}\left(\mathrm{mg} \mathrm{g}^{-1}\right)$ \\
\hline $\mathrm{Ctr}$ & $32.45 \pm 0.85$ & $3.80 \pm 0.08$ & $18.08 \pm 0.13$ & $10.34 \pm 0.58$ & $0.67 \pm 0.80$ \\
\hline H. mes. & $28.67 \pm 0.48 * * * \mathrm{D}$ & $3.75 \pm 0.06$ & $23.12 \pm 0.30 * * * \mathrm{I}$ & $9.72 \pm 0.03$ & $0.80 \pm 0.01 * * * \mathrm{I}$ \\
\hline B. cer. B1 & $35.90 \pm 0.37 * * * I$ & $3.40 \pm 0.06^{* * *} \mathrm{D}$ & $16.94 \pm 0.23 * * * \mathrm{D}$ & $6.99 \pm 0.12 * * * \mathrm{D}$ & $0.695 \pm 0.02$ \\
\hline B. cer. B2 & $41.10 \pm 0.26^{* * *} \mathrm{I}$ & $3.65 \pm 0.12$ & $25.32 \pm 0.27 * * * \mathrm{I}$ & $6.41 \pm 0.25 * * * \mathrm{D}$ & $0.74 \pm 0.02 * * \mathrm{I}$ \\
\hline B. cer. B3 & $34.96 \pm 0.07 * * \mathrm{I}$ & $3.41 \pm 0.08 * * * \mathrm{D}$ & $19.50 \pm 0.57 * * \mathrm{I}$ & $7.67 \pm 0.12 * * * \mathrm{D}$ & $0.81 \pm 0.02 * * * \mathrm{I}$ \\
\hline B. cer. B4 & $35.88 \pm 0.14 * * * I$ & $3.29 \pm 0.08 * * \mathrm{D}$ & $21.72 \pm 0.27 * * * \mathrm{I}$ & $9.19 \pm 0.15^{* *} \mathrm{D}$ & $0.87 \pm 0.01 * * * \mathrm{I}$ \\
\hline H. mes. + B. cer. B1 & $33.31 \pm 0.19$ & $3.93 \pm 0.05 * \mathrm{I}$ & $24.17 \pm 0.58 * * * \mathrm{I}$ & $10.12 \pm 0.03$ & $0.77 \pm 0.02 * * \mathrm{I}$ \\
\hline H. mes + B. cer. B2 & $32.88 \pm 0.32$ & $3.65 \pm 0.05 * \mathrm{D}$ & $20.99 \pm 0.74 * * * \mathrm{I}$ & $8.88 \pm 0.29 * * \mathrm{D}$ & $0.89 \pm 0.02 * * * \mathrm{I}$ \\
\hline H. mes + B. cer. B3 & $33.19 \pm 0.58$ & $3.69 \pm 0.13$ & $21.52 \pm 0.37 * * * \mathrm{I}$ & $7.07 \pm 0.06^{* * *} \mathrm{D}$ & $0.77 \pm 0.03 * * I$ \\
\hline H. mes + B. cer. B4 & $43.71 \pm 1.31 * * * \mathrm{I}$ & $4.13 \pm 0.13 * \mathrm{I}$ & $25.20 \pm 0.99 * * * \mathrm{I}$ & $7.71 \pm 0.22 * * * \mathrm{D}$ & $0.84 \pm 0.04 * * * \mathrm{I}$ \\
\hline $\begin{array}{l}\text { Sufficient nutrition }\left(\mathrm{mg} \mathrm{g}^{-1} \text { ) }\right. \\
\text { (van den Burg 1985) }\end{array}$ & $17.1-25.3$ & $1.0-4.4$ & $7.0-17.6$ & & \\
\hline
\end{tabular}

$I$ increase, $D$ decrease

$* P \leq 0.05 ; * * P \leq 0.01 ; * * * P \leq 0.001$ 
Fig. 3 Electrophoretic separation of total RNA isolated from the leaves of $S$. viminalis in $1.2 \%$ denaturating gel electrophoresis with formaldehyde, stained with etidium bromide.

Lanes: $1 \mathrm{Ctr}, 2 \mathrm{Hm}, 3 \mathrm{~B} 1,4$ $\mathrm{B} 2,5 \mathrm{~B} 3,6 \mathrm{~B} 4,7 \mathrm{Hm}+\mathrm{B} 1$, $8 \mathrm{Hm}+\mathrm{B} 2,9 \mathrm{Hm}+\mathrm{B} 3,10$ $\mathrm{Hm}+\mathrm{B} 4,11$ negative Ctr (noninoculated plants growing at noncontaminated soil) (a). Hybridization northern of molecular probe MT1labeled with digoxygenin to RNA isolated from the leaves of $S$. viminalis clone 87-101 growing in the pot experiment in heavy metalcontaminated soil. Description of lanes as in a (b). Differential expression of MT1 gene in various variants of inoculation. Description of columns as in a (c) a

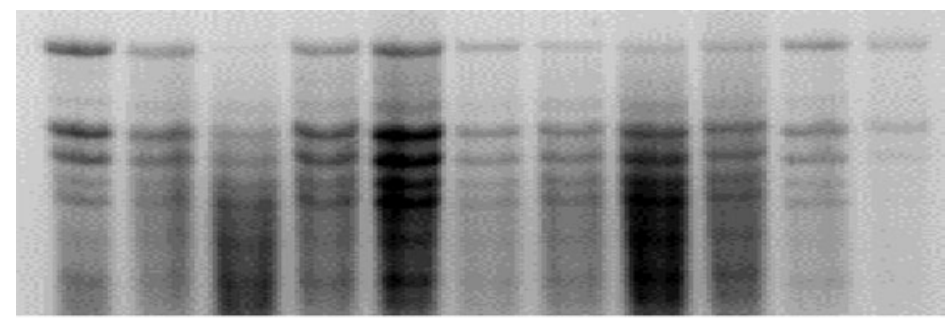

b
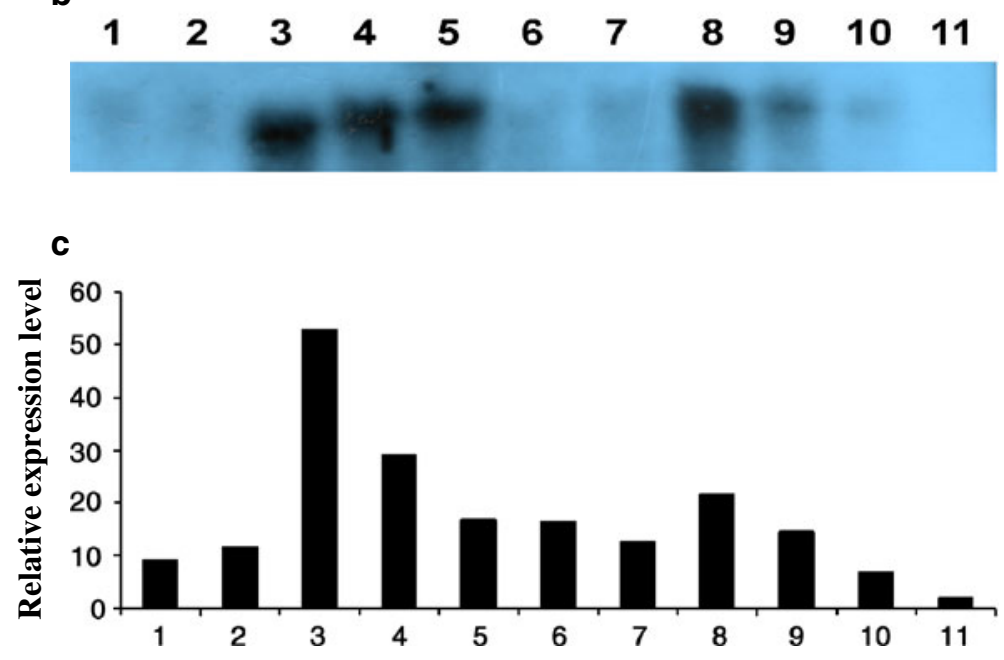

knowledge, in the present work inoculation of willows with $B$. cereus was investigated for the first time. The plant growth promotion after dual inoculation (see Fig. 1a) confirmed the suitability of these inocula for a successful use in phytoremediation.

In agreement with van der Heijden (2001) and Baum et al. (2006), the degree of mycorrhizal colonization was not correlated with the response in the willow growth. In the present study, the nutrient supply of noninoculated (Ctr) $S$. viminalis was above the sufficient level for $\mathrm{N}$ and $\mathrm{K}$ and sufficient for $\mathrm{P}$ (Burg 1985). A sufficient nutrient supply already in the Ctr might be the reason for the relatively small effects of the single inoculation with $H$. mesophaeum on the growth of $S$. viminalis (Hrynkiewicz et al. 2009). Mainly, inoculation increased the nutrient concentrations in the willow leaves compared to the Ctr. However, the $\mathrm{P}$ concentrations were decreased after single inoculation with B. cereus B1, B3 and B4 and after dual inoculation with $H$. mesophaeum and $B$. cereus B2. This might be caused by phosphate accumulation in the cells of $B$. cereus, as described by Rosenberg et al. (1969) and, as a consequence, a decreased P supply to $S$. viminalis. However, since the $\mathrm{N} / \mathrm{P}$ ratio in all treatments was $<11$, the plant growth was rather $\mathrm{N}$ limited (Koerselman and Meuleman 1996). This means that a change in $P$ concentrations should not respond in significant growth changes, as confirmed by the present growth data (see, e.g., strain B3 and B4 in Table 2 and Fig. 1a).

The strongest growth promotion of willows was achieved with dual inoculations with $H$. mesophaeum and the strains B1, B2 and B3 (bacterial strains isolated from EM roots of Hebeloma sp. and Tomentella sp., see Table 1). Application of $H$. mesophaeum with B. cereus B4 (bacteria isolated from a fruit body of $H$. mesophaeum) even decreased willow growth (Fig. 1a), in spite of the strongest promotion of mycorrhiza formation (Fig. 1b). This observation suggests that bacterial strains isolated directly from EM roots of willows might be preferable for fruit body-originating strains. However, since the present study comprised only one bacterial strain from a fruit body (B4), this has to be tested with a broader spectrum of strains before a general validity of this can be assumed. 
Fig. 4 Micrographs of $\mathrm{H}$. mesophaeum isolated from the roots $S$. viminalis growing in heavy metal-contaminated soil in light microscope: simple and dichotomous EM root with white mantle and emanating hyphae $[\times 50](a)$, emanating hyphae with clamps [×400] (b).

Micrographs in electron microscope (TEM): hyphal mantle and penetrating bacterial cells (white arrows) as well as visible plant cells (asterisk), (c) bacterial cell of $B$. cereus inside the plant cell with visible thick (black color) cell wall caused by accumulation of heavy metals in the bacterial cell wall (white arrows) (d and $\mathbf{e})$
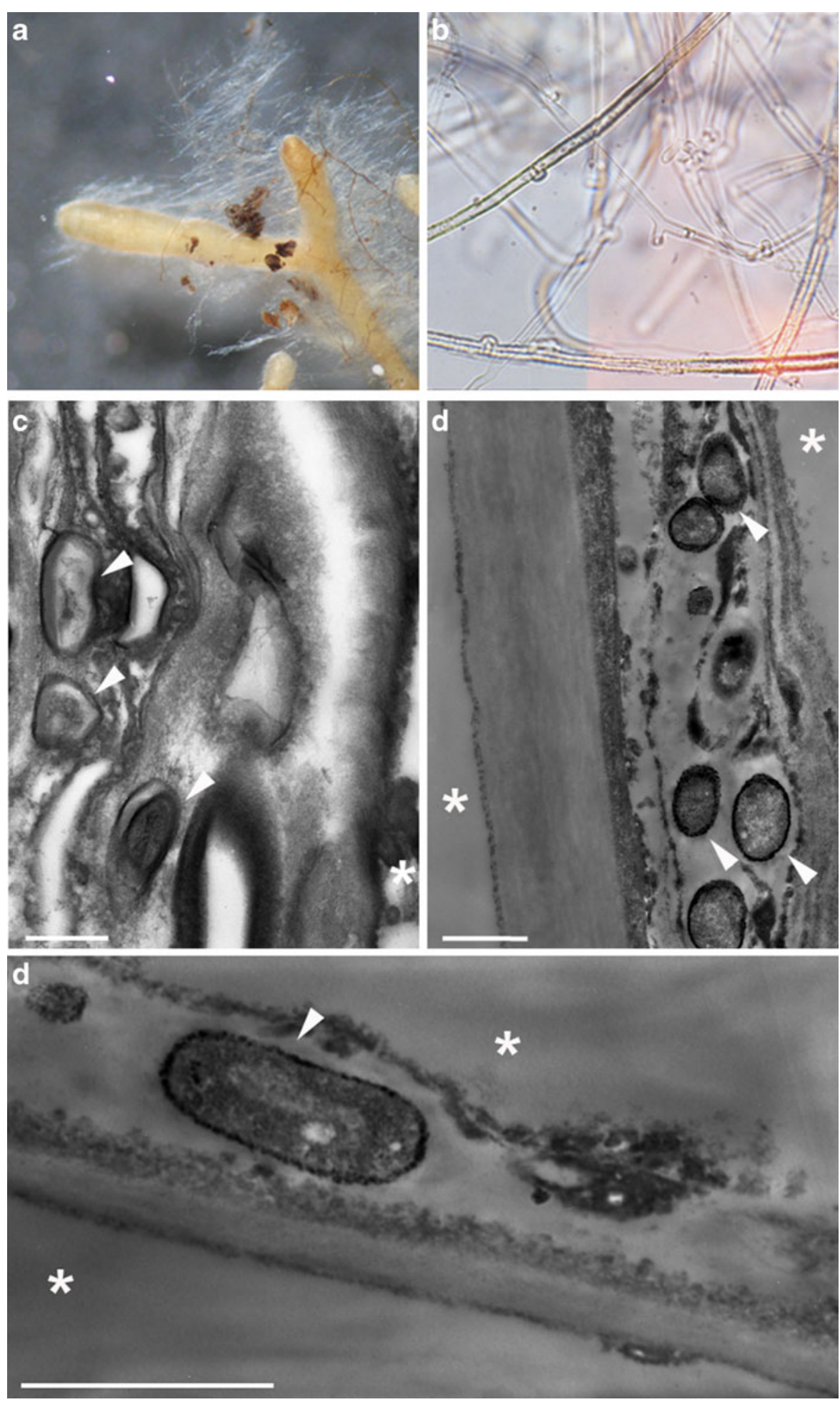

The present study demonstrated for the first time that the expression of metallothioneins MT1 in willows was promoted by inoculation with $B$. cereus strains. The largest $\mathrm{Cd}$ accumulation ( $>20 \%$ higher than the Ctr) after single and dual (with EM fungus) inoculation with $B$. cereus B3 was combined with a 
moderate expression of MTs (Fig. 3). The strongest expression of $M T 1$ after single inoculation with $B$. cereus $\mathrm{B} 1$ was combined with a rather low increase in the Cd uptake into willow stems. This suggested that an increased expression of MT1 in S. viminalis is no indicator of increased plant tolerance against heavy metal stress. Moreover, single inoculation with $B$. cereus B1 and B2 significantly inhibited the growth of S. viminalis. This might be explained by an increased expression of MT1 due to biotic stress through invasive root colonization by $B$. cereus (see Fig. 1) rather than due to abiotic stress through high heavy metal concentrations. This agrees with increased expression of MT1 in the actinorhizal tree Casuarina glauca after infection with the bacterial pathogen $X$. campestris (Obertello et al. 2007). It is also supported by results of Haq et al. (2003), who described that expression of MTs can be induced not only by heavy metals, but also by biotic agents. High expression of MT1 after inoculation with B. cereus B1 and B2 might have decreased the willow growth by an increased energy demand of the plants for expression of MTs (Lanfranco 2006). This is in line with hypersensitivity of Arabidopsis thaliana to $\mathrm{Cd}$ stress after overexpression of phytochelatines (Lee et al. 2003).

The results pointed to a $B$. cereus B3-specific promotion of the Cd uptake into willow stems and a $B$. cereus B4-specific promotion of the $\mathrm{Zn}$ uptake after single and dual inoculations with $H$. mesophaeum. None of the tested inocula caused a combined increase of the $\mathrm{Cd}$ and $\mathrm{Zn}$ uptake by willows. In agreement with our results, a preferable uptake of $\mathrm{Zn}$ compared to $\mathrm{Cd}$ was also observed in peas (Green and Tibbett 2008). Furthermore, in tomato, opposite changes in the $\mathrm{Cd}$ and $\mathrm{Zn}$ uptake were observed (Khan and Khan 1983), although these elements are supposed to behave similar in biological systems (Neibor and Richardson 1980). However, in contrast to our results, joint increases or decreases of the $\mathrm{Cd}$ and $\mathrm{Zn}$ uptake of willows were observed in a field experiment (Hammer et al. 2003). The different results might be explained by diverse interactions in the $\mathrm{Cd}$ and $\mathrm{Zn}$ uptake of plants (Alloway 1990; Kabata-Pendias and Pendias 1999; Badora 2002). Inoculation of $S$. viminalis with H. mesophaeum and/or B. cereus strains B1-B4 caused decreased concentrations of $\mathrm{Cd}$ and increased concentrations of $\mathrm{Zn}$ in all inoculated treatments (Table 2). Decreased Cd concentrations in the host plant after inoculation with a mycorrhizal fungus may have originated from $\mathrm{Cd}$ accumulation in the extramatrical mycelium of this fungus in the soil (Leyval et al. 1997).

In the present study, decreased growth of $S$. viminalis after single inoculation with $B$. cereus strains was observed. Contrarily, Zaidi et al. (2006) reported that a single inoculation with a Bacillus subtilis strain (SJ-101) promoted the growth of $B$. juncea on a metal-polluted soil. Generally, Grampositive bacteria and especially Bacillus spp. can accumulate heavy metals in their cell walls (Collins and Stotzky 1989; Selenska-Pobell et al. 1999; Zaidi and Musarrat 2004). We suggest that strain-specific physiological traits of the bacterial strains control their effects on the growth and metal uptake of willows, as it was observed for other bacterial taxa in S. caprea (Kuffner et al. 2010).

\section{Conclusions}

Inoculation of ectomycorrhizal $S$. viminalis with $B$. cereus might be a promising approach to increase the growth and $\mathrm{Zn}$ extraction at contaminated soils. Compiling the observations in the present study and results from recent publications lead to the suggestion that the origin of bacterial strains (fruit body vs. ectomycorrhiza) for inoculations indicates already specific physiological properties. This hypothesis has to be tested with more strains.

Microorganisms in the rhizosphere are a significant control of MT expression in willows. There seems to be an optimum level of expression of MTs in willows for the tolerance of increased heavy metal concentrations in the soil, above which a growth inhibition might occur. Ectomycorrhizal colonization seems to decrease bacterial penetration into root cells by the outer hyphal mantle, and in this way, seems to limit possible biotic stress in heavy metal-contaminated soils.

Acknowledgements The work was financially supported by the Federal Ministry of Education and Research (Germany, BMBF, contract 02WT0870), the Ministry of Scientific Research and Information Technology (Poland, NN305 187337) and DAAD (A/10/05971). We thank Dr. Steve Robinson (University of Reading, UK) for polishing the language of this manuscript. The anonymous referee is gratefully acknowledged for helpful comments. 
Open Access This article is distributed under the terms of the Creative Commons Attribution Noncommercial License which permits any noncommercial use, distribution, and reproduction in any medium, provided the original author(s) and source are credited.

\section{References}

Agerer, R. (ed.) (1987-2006). Colour atlas of ectomycorrhizae, 1st-12th edn. Einhorn, Schwäbisch Gmünd.

Alloway, B. J. (1990). Heavy metals in soils. Blackie Gosgow and London. New York: Wiley.

Arnesen, L. P. S., Fagerlund, A., \& Granum, P. E. (2008). From soil to gut: Bacillus cereus and its food poisoning toxins. FEMS Microbiology Reviews, 32, 579-606.

Artursson, V., \& Jansson, J. K. (2003). Use of bromodeoxyuridine immunocapture to identify active bacteria associated with arbuscular mycorrhizal hyphae. Applied and Environmental Microbiology, 69, 6208-6215.

Azcón, R., Perálvarez, M. C., Roldán, A., \& Barea, J. M. (2010). Arbuscular mycorrhizal fungi, Bacillus cereus, and Candida parapsilosis from a multicontaminated soil alleviate metal toxicity in plants. Microbial Ecology, 59, $668-677$.

Badora, A. (2002). Bioaccumulation of $\mathrm{Al}, \mathrm{Mn}, \mathrm{Zn}$ and $\mathrm{Cd}$ in pea plants (Pisum sativum L.) against a background of unconventional binding agents. Polish Journal of Environmental Studies, 11, 109-116.

Baum, C., Hrynkiewicz, K., Leinweber, P., \& Meissner, R. (2006). Heavy metal mobilization and uptake by mycorrhizal and non-mycorrhizal willows (Salix $\times$ asyclados). Journal of Plant Nutrition and Soil Science, 169, 516-522.

Belimov, A. A., Safronova, V. I., Sergeyeva, T. A., Egorova, T. N., Matveyeva, V., Tsyganov, V. E., et al. (2001). Characterization of plant growth promoting rhizobacteria isolated from polluted soils and containing 1-aminocyclopropane-1-carboxylate deaminase. Canadian Journal of Microbiology, 47, 642-652.

Bissonnette, L., St-Arnaud, M., \& Labrecque, M. (2010). Phytoextraction of heavy metals by two Salicaceae clones in symbiosis with arbuscular mycorrhizal fungi during the second year of a field trial. Plant and Soil, 332, 55-67.

Burg van den, J. (1985). Folia analysis for determination of tree nutrition saturation-A completation of literature datas, No. 1, Institute for Forestry and Urban Ecology "De Dorschkamp", Wageningen.

Chun-Juan, D., Wang, Y., Shi-Shi, Y., Liu, J.Y. (2010) Characterization of a novel rice metallothionein gene promoter: its tissue specificity and heavy metal responsiveness. Journal of Integrative Plant Biology, 52, 914-924.

Collins, Y. E., \& Stotzky, G. (1989). Factors affecting the toxicity of heavy metals to microbes. In T. J. Beveridge \& R. J. Doyle (Eds.), Metal ions and bacteria (pp. 31-90). New York: Wiley.

Compant, S., Duffy, B., Nowak, J., Clément, C., \& Barka, E. A. (2005). Use of plant growth-promoting bacteria for biocontrol of plant diseases: principles, mechanisms of action, and future prospects. Applied and Environmental Microbiology, 71, 4951-4959.
DalCorso, G., Farinati, S., Maistri, S., \& Furini, A. (2008). How plants cope with cadmium: staking all on metabolism and gene expression. Journal of Integrative Plant Biology, 50, 1268-1280.

Dorsch, M., \& Stackebrandt, E. (1992). Some modifications in the procedure of direct sequencing of PCR-amplified 16SrDNA. Journal of Microbiological Methods, 16, 271-279.

Foley, R. C., Liang, Z. M., \& Singh, K. B. (1997). Analysis of type 1 metallothionein cDNAs in Vicia faba. Plant Molecular Biology, 33, 583-591.

Gardes, M., \& Bruns, T. D. (1993). ITS primers with enhanced specificity of basidiomycetes: application to the identification of mycorrhizae and rusts. Molecular Ecology, 2, 113-118.

Green, I. D., \& Tibbett, M. (2008). Differential uptake, partitioning and transfer of $\mathrm{Cd}$ and $\mathrm{Zn}$ in the soil-pea plant-aphid system. Environmental Science Technology, 42, 450-455.

Hall, J. L. (2002). Cellular mechanisms for heavy metal detoxification and tolerance. Journal of Experimental Botany, 53, 1-11.

Hammer, D., Kayser, A., \& Keller, C. (2003). Phytoextraction of $\mathrm{Cd}$ and $\mathrm{Zn}$ with Salix viminalis in field trials. Soil Use and Management, 19, 187-192.

Haq, F., Mahoney, M., \& Koropatnick, J. (2003). Signaling events for metallothionein induction. Mutation Research, 533, 211-226.

Hrynkiewicz, K., Haug, I., \& Baum, C. (2008). Ectomycorrhizal community structure under willows at former ore mining sites. European Journal Soil Biology, 44, 37-44.

Hrynkiewicz, K., Baum, C., Niedojadło, J., \& Dahm, H. (2009). Promotion of mycorrhiza formation and growth of willows by the bacterial strain Sphingomonas sp. 23 L on fly ash. Biology and Fertility of Soils, 45, 385-394.

Hrynkiewicz, K., Baum, C., \& Leinweber, P. (2010). Density, metabolic activity and identity of cultivable rhizosphere bacteria on Salix viminalis in disturbed arable and landfill soils. Journal of Plant Nutrition and Soil Science, 173, 747-756.

Hrynkiewicz, K., Ciesielska, A., Haug, I., \& Baum, C. (2010). Ectomycorrhiza formation and willow growth promotion as affected by associated bacteria: role of microbial metabolites and use of $\mathrm{C}$ sources. Biology and Fertility of Soils, 46, 139-150.

Hu, X., \& Boyer, G. L. (1996). Siderophore-mediated aluminium uptake by Bacillus megaterium ATCC 19213. Applied and Environmental Microbiology, 62, 4044-4048.

Huang, G. Y., \& Wang, Y. S. (2009). Expression analysis of type 2 metallothionein gene in mangrove species (Bruguiera gymnorrhiza) under heavy metal stress. Chemosphere, 77, 1026-1029.

Janoušková, M., Pavlíková, D., Macek, T., \& Vosátka, M. (2005). Arbuscular mycorrhiza decrease cadmium extraction by transgenic tabacco with inserted metallothionein. Plant and Soil, 272, 29-40.

Jentschke, G., \& Godbold, D. L. (2000). Metal toxicity and ectomycorrhizas. Physiologia Plantarum, 109, 107-116.

Jing, Y., He, Z., \& Yang, X. (2007). Role of soil rhizobacteria in phytoremediation of heavy metal contaminated soils. Journal of Zhejiang University. Science. B, 8, 192-207.

Kabata-Pendias, A., \& Pendias, H. (1999). Biogeochemia Pierwiastków Śladowych, PWN, Warszawa, 75-88 pp. 
Khan, S., \& Khan, N. N. (1983). Influence of lead and cadmium on growth and nutrient concentration of tomato (Lycopersicum esculentum) and eggplant (Solanum melongera). Plant and Soil, 74, 387-394.

Koerselman, W., \& Meuleman, A. F. M. (1996). The vegetation $\mathrm{N}: \mathrm{P}$ ratio: a new tool to detect the nature of nutrient limitation. Journal of Applied Ecology, 33, 1441-1450.

Kottke, I., Guttenberger, M., Hampp, R., \& Oberwinkler, F. (1987). An in vitro method for establishing mycorrhizae on coniferous tree seedlings. Trees, 1, 191-194.

Kozdrój, J., Piotrowska-Seget, Z., \& Krupa, P. (2007). Mycorrhizal fungi and ectomycorrhiza associated bacteria isolated from an industrial desert soil protect pine seedlings against Cd(II) impact. Ecotoxicology, 16, 449-456.

Kuffner, M., Puschenreiter, M., Wieshammer, G., Gorfer, M., \& Sessitsch, A. (2008). Rhizosphere bacteria affect growth and metal uptake of heavy metal accumulating willows. Plant and Soil, 304, 35-44.

Kuffner, M., De Maria, S., Puschenreiter, M., Fallmann, K., Wieshammer, G., Gorfer, M., et al. (2010). Culturable bacteria from $\mathrm{Zn}$ - and Cd-accumulating Salix caprea with differential effects on plant growth and heavy metal availability. Journal of Applied Microbiology, 108, 1471-1484.

Landberg, T., \& Greger, M. (2004). No phytochelatin (PC2 and PC3) detected in Salix viminalis. Physiologia Plantarum, $121,481-487$.

Lanfranco, L. (2006). The fine-tuning of heavy metals in mycorrhizal fungi. The New Phytologist, 174, 3-6.

Lee, S., Moon, J. S., Ko, T. S., Petros, D., Goldsbrough, P. B., \& Korban, S. S. (2003). Overexpression of Arabiopsis phytochelatin synthase paradoxically leads to hypersensitivity to cadmium stess. Plant Physiology, 131, 656-663.

Leyval, C., Turnau, K., \& Haselwandter, K. (1997). Effect of heavy metal pollution on mycorrhizal colonization and function: physiological, ecological and applied aspects. Mycorrhiza, 7, 139-153.

Neibor, E., \& Richardson, D. H. S. (1980). The replacement of the nondescript term "heavy metals" by a biological and chemically significant classification of metal ions. Environmental Pollution B, 1, 3-26.

Obertello, M., Wall, L., Laplaze, L., Nicole, M., Auguy, F., Gherbi, H., et al. (2007). Functional analysis of the metallothionein gene $c g M T 1$ isolated from the actinorhizal tree Casuarina glauca. Molecular Plant-Microbe Interactions, 20, 1231-1240.

Ozkuthu, F., Sekeroglu, N., \& Kara, S. M. (2006). Monitoring of cadmium and micronutrients in spices commonly consumed in Turkey. Research Journal of Agriculture and Biological Sciences, 2, 223-226.

Rosenberg, H., Medveczky, N., \& La Nauze, J. M. (1969). Phosphate transport in Bacillus cereus. Biochimica et Biophysica Acta (BBA)-Biomembranes, 193, 159-167.

Sambrook, J., Fritschi, E. F., \& Maniatis, T. (1989). Molecular cloning: A laboratory manual. New York: Cold Spring Harbor Laboratory.

Scott, D., \& Albert, L.L. (2005). Maize metallothionein promoter. Patent Publication n. WO/2005/063997.
Selenska-Pobell, S., Panak, P., Miteva, V., Boudakov, I., Bernhard, G., \& Nitsche, H. (1999). Selective accumulation of heavy metals by three indigenous Bacillus strains, $B$. cereus, B. megaterium and B. sphaericus, from drain waters of a uranium waste pile. FEMS Microbiology Ecology, 29, 59-67.

van der Heijden, E. W. (2001). Differential benefits of arbuscular mycorrhizal and ectomycorrhizal infection in Salix repens. Mycorrhiza, 10, 185-193.

Vessey, J. K. (2003). Plant growth promoting rhizobacteria as biofertilizers. Plant and Soil, 255, 571-586.

Voiblet, C., Duplessis, S., Encelot, N., \& Martin, F. (2001). Identification of symbiosis-regulated genes in Eucalyptus globulus-Pisolithus tinctorius ectomycorrhiza by differential hybridization of arrayed cDNAs. The Plant Journal, 25, 181-191.

Wang, Y., \& Greger, M. (2004). Clonal differences in mercury tolerance, accumulation, and distribution in willow. Journal of Environmental Quality, 33, 1779-1785.

Wenzel, W. W. (2009). Rhizosphere processes and management in plant-assisted bioremediation (phytoremediation) of soils. Plant and Soil, 321, 385-408.

Whiting, S. N., de Souza, M. P., \& Terry, N. (2001). Rhizosphere bacteria mobilize $\mathrm{Zn}$ for hyperaccumulation by Thlaspi caerulescens. Environmental Science \& Technology, 35, 3144-3150.

Wu, S. C., Cheung, K. C., Luo, Y. M., \& Wong, M. H. (2006). Effects of inoculation of plant growth-promoting rhizobacteria on metal uptake by Brassica juncea. Environmental Pollution, 140, 124-135.

Xu, X., Sourè, A., Granier, C., Petitprez, M. (1995) An improved immunolabeling method for microtubular cytoskeleton in poplar (Populus nigra L.) free nuclear endosperm. Biotechnic \& Histochemistry, 70, 252-257.

Zacchini, M., Pietrini, F., Mugnozza, G. S., Iori, V., Pietrosanti, L., \& Massacci, A. (2009). Metal tolerance, accumulation and translocation in poplar and willow clones treated with cadmium in hydroponics. Water, Air, and Soil Pollution, 197, 23-34.

Zaidi, S., \& Musarrat, J. (2004). Characterisation and nickel sorption kinetics of a new metal hyper-accumulator Bacillus sp. Journal of Environmental Science and Health A, 39, 681-691.

Zaidi, S., Usmani, S., Singh, B. R., \& Musarrat, J. (2006). Significance of Bacillus subtilis strain SJ-101 as a bioinoculant for concurrent plant growth promotion and nickel accumulation in Brassica juncea. Chemosphere, 64, 991-997.

Zhu, J., Zhang, Q., Wu, R., \& Zhang, Z. (2010). HbMT2, an ethephon-induced metallothionein gene from Hevea brasilienis responds to $\mathrm{H}_{2} \mathrm{O}_{2}$ stress. Plant Physiology and Biochemistry, 48, 710-715.

Zimmer, D., Baum, C., Leinweber, P., Hrynkiewicz, K., \& Meissner, R. (2009). Associated bacteria increase the phytoextraction of cadmium and zinc from metalcontaminated soil by mycorrhizal willows. International Journal of Phytoremediation, 11, 200-213. 